\title{
Lektioita
}

Virve Repo ${ }^{\mathrm{a}}$

\section{Tilaan tuomittu: näkökulmia vankeusmaantieteeseen}

\section{Väitöstilaisuuden Lectio Praecursoria Turun Yliopisto I.8.2020}

Alkuvuonna 2020 koronaviruspandemia levisi nopeasti maailmanlaajuisesti. Maaliskuussa Suomen hallitus julisti poikkeustilan, jolla pyrittiin estämään viruksen leviäminen. Koulut suljettiin, kiellettiin vierailut vanhusten ja muiden riskiryhmien asumispalveluyksiköissä, yli 70-vuotiaita ohjeistettiin pysymään karanteenissa ja muitakin kehotettiin pysymään kotona ja asioimaan ulkona vain välttämättömissä tapauksissa. Rajoja alettiin sulkea, joksikin aikaa jopa Uudenmaan ja muun Suomen väliltä.

Näinä poikkeuksellisina aikoina olemme kaikki joutuneet kokemaan, miten liikkumistamme ja elämistämme rajoitetaan. Varsin monelle lienee tullut myös selväksi, miten tilalla ja tilallisilla ratkaisuilla on merkitystä siihen, miten arkielämä sujuu, jos joudutaan pysyttelemään neljän seinän sisällä. Koti ja kodin tilat koetaan uudella tavalla, kun kodista tuleekin yhtäkkiä työpaikka, koulu sekä harrastus- ja vapaa-ajanviettopaikka.

Järjestelmää ja kontrollia toki tarvitaan aina jossain määrin. Joissain tapauksissa rajoittaminen ja kontrolli kuitenkin eskaloituvat, mikä synnyttää tietyntyyppisiä rajoittamismenetelmiä ja rajoitettuja tiloja. Viime vuosina käydyt keskustelut väärinkäytöksistä vanhusten hoidon ja psykiatrisen hoidon kohdalla ovatkin toimineet yhtenä motivaationa tämän tutkimuksen tekemiselle.

Väitöskirjassani lähestyn rajoittamisen teemaa tilallisesta näkökulmasta ja tarkastelen rajoitettuja tiloja erityisesti vankeusmaantieteen teoreettiseen viitekehykseen nojaten. Vankeusmaantiede tunnetaan englanniksi nimellä carceral geography, ja siihen perustuva tutkimus on varsin uutta Suomessa. Siten se antaakin mahdollisuuden tarkastella suomalaisia instituutioita täysin uudesta näkökulmasta. Vaikka vankeusmaantieteen juuret ovat vankilatutkimuksessa, viime aikoina tätä teoreettista lähestymistapaa on käytetty myös muiden rajoitettujen tilojen tutkimukseen. Koenkin, että ottaessaan huomioon erilaisten rajoitusten vaikutukset tilaan, vankeusmaantiede toimii erinomaisesti myös hoitoinstituutioita ja muita rajoitettuja tiloja tutkittaessa.

Väitöskirjassani kysyn: Millaisia vankeuskäytäntöjä ja -prosesseja rajoitetuista tiloista voidaan tunnistaa? Millaisia vankeustiloja nämä käytännöt ja prosessit muodostavat? Kysyn myös, miten vankeustiloja voidaan edelleen määritellä ihmismaantieteessä? Tutkimuksessa ymmärrän ihmismaantieteelle tyypillisesti tilan muodostuvan sen fyysisten rakenteiden

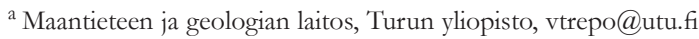


lisäksi vuorovaikutuksessa ihmisten, esineiden ja esimerkiksi säännösten kanssa. Tutkimuksessani olen myös erotellut rajoitetut tilat (spaces of confinement) ja vankeustilat (carceral spaces) toisistaan. Rajoitetut tilat näen laajempana käsitteenä, jonka alle esimerkiksi erilaiset vankeustilat kuuluvat. Näkemykseni mukaan rajoitetut tilat syntyvät kontrollin, valvonnan ja fyysisten esteiden avulla ja ne on perinteisesti yhdistetty laitoksiin. Fyysiset esteet eivät kuitenkaan aina määritä rajoitettua tilaa, sillä esimerkiksi kameravalvonta, elektroninen monitorointi ja lait määrittelevät ihmisten liikkumista. Lait ja valvonta voivat toki lisätä ihmisten turvallisuuden tunnetta. Kolikon toinen puoli on, että ihmisiä kontrolloidaan turvallisuuteen vedoten joskus jopa liioitellusti.

Tässä väitöskirjassa vankeustiloiksi määritellään sellaiset rajoitetut tilat, jotka tuottavat kärsimystä ihmisille. Vankeustilan voidaankin ajatella koostuvan kolmen määritelmän kombinaatiosta. Vahinko, tarkoituksellisuus ja tilallisuus. Ihmistä siis tarkoituksella pidetään jossain tilassa, aiheuttaen hänelle vahinkoa. Nämä tilat ovat syntyneet virallisten ja epävirallisten järjestelmien tai yksittäisten henkilöiden ja ryhmien tuottamina. Tällaisiksi tiloiksi voidaan yleisesti lukea esimerkiksi vankilat, joiden pääasiallinen tarkoitus on ollut, hyvinkin yksinkertaistettuna, rankaista lain rikkojia.

Asia ei kuitenkaan ole näin yksiselitteinen. Vankeusmaantieteessä vankeus nähdään suhteellisena. Vankeus ei siis välttämättä tarkoita vankeusrangaistusta vaan se voidaan nähdä ihmisen omaan kokemukseen perustuvana. Tällä tarkoitan, että ihmiset, jotka eivät ole rikosoikeudellisesti vankeja, voivat kokea olevansa vankeja erilaisista syistä. Joskus onkin vaikea tunnistaa rajoitettujen tilojen ja vankeustilojen eroa, mikä saattaa aiheuttaa haasteita esimerkiksi laitoksissa.

Tarkastelen rajoitettuja tiloja neljän artikkelin avulla. Näistä neljästä artikkelista ensimmäinen, kolmas ja neljäs ovat tehty kokonaan Suomen Akatemian rahoittamissa hankkeissa Nomospheres of publicity ja Spaces of Confinement. Toiseen artikkeliin sain apurahaa myös muun muassa Miina Sillanpään säätiöltä. Ensimmäinen artikkeli käsittelee Kööpenhaminassa sijaitsevan Christianian vaihtoehtoyhteisön muuttunutta tilannetta alueen omistussuhteiden myötä. Muutos oli osa Kööpenhaminan kaupungin pitkään jatkunutta yritystä normalisoida Christiania ja liittää heidät tavallisen lainsäädännön piiriin. Lakimuutoksen myötä monen christianialaisen koti purettiin tai ne määrättiin siirrettäväksi toiseen paikkaan. Muuttunut tilanne jakoi mielipiteitä myös asukkaiden parissa ja joitain toisinajattelevia alettiin säännönmukaisesti sulkemaan ulos yhteisöstä, heidän asuntojaan vandalisoitiin ja heitä uhkailtiin. Kaupungin jatkuvien rajoituspyrkimysten lisäksi yhteisön jäsenet alkoivat nyt siis rajoittaa myös toisiaan. Tilanne johti siihen, että joidenkin ihmisten kotien voidaan katsoa muuttuneen vankeustiloiksi, sillä he kokivat olonsa turvattomaksi paitsi kodin ulkopuolella myös kodeissaan. Christianian esimerkki osoittaa, että vankeustiloja voi syntyä myös esimerkiksi yhteisöjen sisällä.

Toinen artikkeli käsittelee tilallisen kontrollin ja hoivan suhdetta suomalaisissa vanhainkodeissa. Lisääntynyt muistisairaiden määrä aiheuttaa haasteita hoivalle. Osaksi erityisesti siitä syystä, että ajan ja paikan orientaation heikentyminen kuuluu sairaudenkuvaan. Laitosolosuhteissa hoidettavat muistisairaat vanhukset eivät välttämättä hahmota olinpaikkaansa, vaan he voivat kuvitella olevansa esimerkiksi risteilyllä, koulussa tai pahimmassa tapauksessa vankilassa. Tällaisissa tiloissa fyysiset rajoitukset, kuten lukot ja suljetut ovet ovat osin tarpeellisia turvallisuussyistä. Kuitenkin, hoivan ja kontrollin välinen suhde on herkkä ja joissain tapauksissa liiallinen kontrolli voidaan nähdä hoivana. Lisäksi hoivan tuotteistaminen sekä riittämätön hoitajamitoitus aiheuttavat kiirettä, mikä altistaa vanhukset kaltoinkohtelulle. Tuotteistamisen ja hoitajamitoituksen kautta hoivan kysymykset sitoutuvat myös laajempiin yhteiskunnallisiin kysymyksiin ja asenteisiin.

Kolmannessa tapauksessa paneudun Turussa sijaitsevan Kupittaan psykiatrisen sairaalan vanhuspsykiatrisen osaston tapahtumiin. Osaston potilaita oli silminnäkijöiden mukaan käsitelty kovakouraisesti, eristetty ilman lääkärin lupaa ja heille oli syötetty ylimääräisiä lääkkeitä. Joissain tapauksissa pahoinpitelyn tunnusmerkit täyttyivät. Poliisin tutkinnan 
jälkeen syytteeseen joutui yhteensä neljä hoitajaa, joista kaksi sai käräjäoikeudessa tuomion. Tuomiot kuitenkin kumottiin myöhemmin hovioikeudessa. Kolmannessa artikkelissani käsittelen oikeudessa luettujen syytekohtien kautta, millaisia vankeustiloja osastolla syntyi väitetyn kaltoinkohtelun myötä.

Neljännessä artikkelissa jatkan saman tapauksen käsittelyä. Tässä artikkelissa yhdistän riskin ja vankeustilojen käsitteet ja tarkastelen, miten käsitys riskeistä vaikuttaa vankeustilojen syntyyn työyhteisössä. Tutkimuksessa selvisi, että työyhteisössä oli pahoja vastakkainasetteluja vanhojen ja uusien työntekijöiden välillä. Jotkut kokemusvuosiltaan vanhemmat työntekijät halusivat ylläpitää perinteisiä, joskus jopa vanhanaikaisia hoitomenetelmï̈. Työntekijät, jotka uskalsivat huomauttaa niistä, kokivat tulleensa kiusatuksi tai ulossuljetuksi työyhteisöstä. Vaikka epäkohdista kerrottiin johtavalle portaalle, asiat painettiin villaisella, eikä niitä otettu välttämättä käsittelyyn johdon tasolla. Näin ollen myös johtava porras salli huonon työkulttuurin muodostumisen, sillä valituksia ei aina käsitelty eikä niitä viety eteenpäin. Lisäksi uskottiin, että valittajat koettiin hankaliksi, eikä heidän työsopimuksiaan välttämättä uusittu. Riski kiusatuksi tulemisesta tai työn loppumisesta johti siihen, että jotkut työntekijät joutuivat tahtomattaan vedetyksi mukaan vinoutuneeseen työkulttuuriin.

Väitöskirjani tarjoaa myös kaksi uutta käsitteellistä näkökulmaa rajoitettujen tilojen tarkasteluun. Kolmannen artikkelin tulokset osoittavat, että vankeustilat muodostuvat erilaisista päällekkäisistä ja toisiinsa limittyvistä kerrostumista, jotka saattavat kasautua joihinkin tiettyihin tiloihin tehden niistä rajoittavampia kuin toisista. Esimerkiksi psykiatrisen sairaalan eristyshuonetta koskevia sääntöjä ja lakeja on enemmän kuin koko osastoa koskevia sääntöjä. Lisäksi, jos eristyshuonetta käytetään rangaistusmetodina vääränlaisesta käytöksestä tuo se täysin uusia vankeustiloja muodostavia prosesseja esiin.

Neljännessä artikkelissa tarkastelemani riskien ja vankeustilojen välisen suhteen tutkiminen paljastaa, miten näkemykset riskeistä saattavat tuottaa vankeuskäytäntöjä ja -tiloja. Riskit ovat olennainen osa laitoselämää ja erilaisia riskiarvioita tehdään laitoksissa jatkuvasti. Vaikka riski voidaan määritellä joksikin, joka ei ole vielä tapahtunut, riskit saattavat alkaa hallita elämää ja sitä myötä muovaamaan ihmisten käytöstä. Jos esimerkiksi hoitohenkilökuntaan kuuluva kokee työpaikkansa riskiympäristönä, se vaikuttaa vääjäämättä henkilökunnan jäsenen hyvinvointiin ja sitä kautta myös mahdollisesti hoidon laatuun. Erityisesti, jos tällainen riskiympäristö syntyy työtovereiden toimesta.

Väitöskirjatutkimukseni osoittaa, että ihmisten elämää rajoitetaan moninaisista syistä. Ensinnäkin, ihmiset, joiden koetaan olevan riski yhteiskunnalle, muille ihmisille tai itselleen ovat usein rajoituskäytäntöjen kohteena. Rajoittavilla käytännöillä pyritään vaikuttamaan heidän käytökseensä ja sopeuttamaan heitä ympäröivään yhteiskuntaan. Rajoitusmenetelmät ovat tyypillisiä perinteisten vankeusrangaistusten kohdalla, mutta vastaavanlaisia toimia voidaan soveltaa myös ihmisiin, joiden käytöstä tai ajattelumalleja yritetään normalisoida. Hoivainstituutiotkaan eivät ole vapaita tällaisesta ajatusmallista, jossa ihmisten täytyy käyttäytyä tietyllä tavalla. Rajoittavat toimet saattavatkin tuntua kohtuuttomilta sellaisten ihmisten kohdalla, jotka eivät syystä tai toisesta pysty säätelemään käytöstään. Esimerkiksi muistisairaiden on vaikea erottaa laitosmaisia paikkoja toisistaan, mikä saattaa tuntua ahdistavalta, varsinkin jos kokee tulleensa vangituksi. Lisäksi kykenemättömyys erottaa laitoksia toisistaan vaikuttaa siihen, miten kokemukset yhdessä laitoksessa siirtyvät ihmisen mielessä myös toisiin vastaaviin laitoksiin. Esimerkiksi negatiiviset kokemukset lääkkeenotosta tai pakkotoimista yhdessä laitoksessa saattavat vaikuttaa ihmisen aggressiivisuuteen samankaltaisissa tilanteissa myös muissa laitoksissa. Voidaankin sanoa, että laitoskokemukset kerrostuvat ihmiselämään luoden institutionaalisen taakan, joka seuraa kantajaansa laitoksesta toiseen.

Vaikka varsinaisten vankeustilojen ei voidakaan katsoa syntyvän lääketieteellisistä syistä, vaan ne tarvitsevat toteutuakseen aina tarkoituksellisuuden, tutkimukseni osoittaa, että tietyt lääketieteelliset seikat altistavat rajoitettujen tilojen kokemiselle. Esimerkiksi muistisairaat 
voivat kokea rajoitukset hyvinkin eri tavalla ajan ja paikan orientaation puuttuessa. Myös liikuntarajoitteiset vanhukset voivat joutua hoivalaitoksissa olemaan pitkiä aikoja yksin, mikä altistaa ahdistuneisuudelle ja yksinäisyydelle ja jopa tilalliselle kaltoinkohtelulle.

Tilallisella kaltoinkohtelulla tarkoitan varsinkin laitoksissa tapahtuvaa liikkumisen rajoittamista tai esimerkiksi ulkoilun puuttumista. Vaikka ulkoilematta jättäminen voi olla myös ihmisen oma valinta, se altistaa laitostumiselle, joka puolestaan vaikuttaa vahvasti elämänlaatuun. Varsinkin vanhusten kohdalla tilallinen kaltoinkohtelu on myös yhteydessä hoitajakapasiteettiin ja heidän mahdollisuuksiinsa viedä vanhuksia ulos.

Tutkimuksessa kiinnitän myös huomiota eskapismiin. Mielikuvituksen tai jopa kuvitteellisen vapaudentunteen kautta ihminen voi mielessään paeta laitosoloja. Ajankulkuun vaikuttavat myös mahdollisuudet erilaisiin toimintoihin, jotka vievät ajatukset pois rutiineista, odottamisesta ja tylsyydestä. Erityisesti vanhustenhoidossa on alettu kiinnittää huomiota erilaisiin kulttuuri- ja virkistystoimintoihin, jotka ovatkin tervetullut lisä laitoshoitoon niin toteutuessaan.

Rajoitetut tilat tuottavat moraalisesti harmaita alueita. Nämä harmaat alueet ilmenevät esimerkiksi niissä tapauksissa, joissa moraalisesti arveluttavat keinot, kuten liiallinen läkikitseminen tai huoneeseen lukitseminen, katsotaan oikeutetuiksi, jotta osasto pysyisi rauhallisena toisen yöhoitajan nukkuessa, kuten Kupittaan tapauksessa. Tyypillistä harmaille alueille on, että ihmiset joutuvat painostuksen alla tekemään itselleen epämiellyttäviä ratkaisuja. Tällöin ihminen voi tahtomattaan ajautua toteuttamaan sellaisia käytäntöjä, jotka hän kokee moraalisesti arveluttavaksi. Harmaat alueet voivat liittyä myös lakiin ja kuvata sellaisia toimintoja, joissa lain laveat tulkinnat lipsuvat laittomuuksien puolelle.

Myös sekä yhteiskunnallisilla että ihmisten välisillä valtasuhteilla on merkitystä siinä, ketkä rajoitettuja tiloja ja vankeustiloja kokevat. Tietyillä ihmisillä on suurempi valta kontrolloida, käyttää fyysistä voimaa, rajoittaa liikkumista, määritellä milloin muut saavat nukkua ja syödä. Vaikka rajoitukset voidaankin nähdä laitoksissa jossain määrin terapeuttisena toimintana ja kuntouttamisena, aina näin ei kuitenkaan ole. Epätasa-arvoiset valtasuhteet mahdollistavat kaltoinkohtelun ja sen jatkumisen, jos ylemmässä asemassa olevat auktoriteetit eivät puutu väärinkäytöksiin ajoissa.

Vankeustilat voivat syntyä virallisten prosessien, kuten lakien ja säännösten seurauksena. Varsinkin laitoksissa hallintojärjestelmällä on suuri vaikutus prosesseihin, sillä sen avulla luodaan raamit, joiden sisällä elää ja toimia esimerkiksi lainsäädännön ja budjetoinnin avulla. Vaikka järjestelmän avulla yritetään ylläpitää yhteiskuntaa kokonaisuudessaan, nämä prosessit vaikuttavat eskaloituessaan arvaamattomilla tavoilla ihmisten henkilökohtaiseen elämään. Yhteiskunnalliset mekanismit ovat myös yhteydessä vangitsemislogiikkaan, jonka avulla voidaan esimerkiksi tiettyjä ihmisryhmiä rajoittaa, koska heidät koetaan vaarallisiksi.

Väitänkin, että rajoitetut tilat luovat ihmisryhmiä, jotka ovat toisia havoittuvampia. Nämä ihmisryhmät altistuvat syystä tai toisesta vakaville rajoituksille enemmän kuin toiset. Nämä ihmiset ovat tehostetun kontrollin alaisia ja heidän täytyy muokata käyttäytymistään ja tekojaan välttääkseen konfliktitilanteet. Tässä tutkimuksessa sellaisia ryhmiä ovat esimerkiksi Christianian toisin ajattelevat ihmiset sekä ne psykiatrisen osaston työntekijät, jotka eivät halunneet olla mukana huonoissa hoitokäytännöissä.

Yksi ryhmä nousee kuitenkin tutkimuksessa ylitse muiden. Muistisairaiden ihmisten haavoittuvuus tuli vahvasti esiin tässä tutkimuksessa. Lyhytkestoisen muistin puute altistaa muistisairaat kaltoinkohtelulle. Lisäksi, ottaen huomioon sairauden aiheuttaman sekavuuden ajasta ja paikasta, muistisairaat voivat joutua myös tahattoman kaltoinkohtelun kohteeksi. Jokin, mikä on lähtöisin hyvistä tarkoitusperistä voi muistisairaasta tuntua kaltoinkohtelulta. Lisäksi nämä rajoittamiskokemukset seuraavat ihmisen mukana pitkiäkin aikoja ja vaikuttavat muun muassa ihmisen kykyyn arvioida riskejä ja selviytyä. Koenkin, että on tärkeä havaita ja tutkia rajoitettuja tiloja ja prosesseja niiden takana, sillä niiden vaikutus ihmisten hyvinvointiin on kiistaton. 
Lopuksi, tilalla on merkitystä. Suomalaista laitoshoitoa on purettu systemaattisesti 1970-luvulta lähtien. On kuitenkin tutkittu, että laitoshoidon purkaminen esimerkiksi mielenterveyspuolella ei välttämättä ole onnistunut täydellisesti. Tämä johtuu muun muassa siitä, että laitoksille tyypilliset ominaisuudet ovat siirtyneet muihin hoitomuotoihin. Ranskalainen filosofi Michel Foucault on kirjoittanut, että sana "laitos" on vaarallinen, sillä kun ajattelemme laitosta, otamme siihen liittyvät rajoitukset ja ominaisuudet itsestäänselvyytenä. Tämän vuoksi se, millaisena laitokset nähdään, onkin syytä uudelleenarvioida. Tällaista kehitystä onkin jo tapahtunut ympäri Eurooppaa, myös Suomessa. Sekä laitoshoidon muotoja, että fyysisiä raameja on alettu uudelleen arvioida ja suunnitella. Jo nyt on kuitenkin huomattu, että vaikka perinteisiä laitoksia on ajettu alas, niiden rakenteet ja toimintamekanismit siirtyvät helposti myös uudenlaisiin hoitomuotoihin. Vankeusmaantieteen monimuotoinen näkemys tilasta ottaa huomioon arkkitehtuuristen ratkaisujen lisäksi valtarakenteiden uudelleen arvioinnin, sekä työolosuhteiden ja työkapasiteetin merkityksen. Vankeusmaantieteen näkökulma tuokin uudenlaista perspektiiviä ja on hyödyllinen, jollei jopa välttämätön etenkin laitoshoidon suunnittelussa.

\section{Lähteet}

Foucault, M. (2006) Psychiatric power. Lectures at the Collegé de France 1973-1974. Picador, New York.

\section{Väitöskirjan tiedot}

Repo, V. (2020) Confined to Space: Perspectives on Carceral Geography. Turun yliopiston julkaisuja AII: 371 I, Biologica - Geographica - Geologica. Turun yliopisto, Turku. http://urn.fi/URN:ISBN:978-951-29-8103-8 